\title{
CAを用いたミクロな宅地用途シミュレーションモデルの開発と適用 STUDY ON DEVELOPMENT AND APPLICATION OF MICRO SIMULATION MODEL FOR LOT USAGE TRANSITION USING CA
}

\author{
沈 振 江*, $^{*}$ 川上光彦**, 川村一平***, 加藤千智**** \\ Zhenjiang SHEN, Mitsuhiko KAWAKAMI, Ippei KAWAMURA \\ and Kazutomo KATO
}

\begin{abstract}
In this paper, a simulation system using $\mathrm{CA}$ is suggested in order to visualize land use patterns in a built-up area after development. A land use simulation system using CA is usually developed in a regular grid net or a network, where the spatial relationship of the adjacent grids or network is easily dealt with. A new concept in this project is the exploration of how to deal with spatial micro simulation in land use patterns of plots in blocks while considering the influence of the road network. Irregular adjacent plots in blocks and relevant plots on the other side of the road network are the intended simulation targets. In this paper, a prototype simulator is discussed regarding how to simulate land use patterns after land readjustment projects. In order to examine the effects of the simulation system, we chose one study area in Kanazawa city. However, the simulation of households, energy expenditure and traffic volumes based on land use pattern is left as our further research, in which households, energy expenditure and traffic volumes can be calculated according to statistical indicators of the Ishikawa province and National Statistics office.
\end{abstract}

Keywords: CA, Land Readjustment Project, land use, usage transition $\mathrm{CA}$, 土地区画整理事業, 土地利用, 用途変遷

1.はじめに

近年, 都市計画事業の遂行などにおいてより一層の住民参加が求 められてきている，そのため, 本研究では, 計画設計段階で将来市 街地像を提示できる計画支援ツールの開発することを目的にしてい る. 地区レベルの市街地において, 計画設計条件などによる宅地単 位のミクロな市街地形成をシミュレーションし, 視覚化することが できれば，計画設計段階で都市の将来像をよりイメージしやすく理 解することができる. 土地区画整理事業の場合, 减歩や換地により 宅地区画が整理されるが，施行後における市街地像が計画設計段階 で想定しにくく，事業後における共通な市街地像イメージの提示が 重要な課題である. 将来市街地像には, 宅地用途, 建物形態, 街並 み景観などの提示が必要であり, 持続可能な地域社会構築という観 点から, 環境影響の状況を提示することも重要である。一般的には, 利用者が宅地用途や建物形態の基本方針を決めれば, 用途地域など の規制にもとづいて建築可能な空間形態がほぼ確定でき，それにも とづいて居住人口や車の所有数の推測も可能で，街並み景観のイメ ージもある程度提示できる.このうち, 宅地用途の決定は, 市街地像 を提示するための重要な前提と考えられる.

本研究では，将来市街地像を提示するため，用途地域や前面道路 などの計画設計条件の影響によって事業後の宅地用途の変遷をシミ ユレーションすることが可能であれば, 敷地関連規制, 宅地の形状 や面積によって建築可能な空間の推測が可能になり，街並み景観を シミュレーションすることも可能と考えている，本稿では, 計画設
計条件の影響を中心に, 宅地用途シミュレーションのモデル構築を 試みたい。

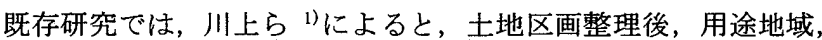
前面道路および角地の計画設計条件が宅地用途の形成要因であると している. また，マニルザマンら ${ }^{2)}$ と沈ら ${ }^{3)}$ は，宅地の幾何的特性 も用途の形成に影響があることを指摘している，一方，計画支援シ ステムの分野において，セルオートマトン(以下 CA)を用いた市街地 形成シミュレーションシステムの開発が行われてきている. CA を用 いる利点は, 単純なルールによって時間的推移による都市空間の成 長, 空間パターンの変化を扱うことができることが挙げられる.こ れまで, アーバンスプロールのシミュレーションに関して, 多くの 研究事例, 例えば, Fulong Wu ${ }^{4)}$, Claudia M., M. Batty 他 ${ }^{5)}$ が行な った研究が報告されており, Beneson と P.M. Torren ${ }^{6)}$ が関連の研究 事例を本の形でとりまとめている. これまで，土地利用の変遷をメ ッシュ単位で一定ルールによりシミュレーションできるようにして きたが，Ivan Blecich 他 ${ }^{7)}$ と Erickson 他 ${ }^{8)}$ が報告した非規則的ボ ロノイやポリゴンデータに対して CA を適用したような事例は少な い. 渡辺ら ${ }^{9)}$ と瀧澤ら ${ }^{10)}$ は， CA を用いて都市をマク口的に扱い，セ ル単位で都市拡大シミュレーションを行っている，渡边らのモデル では，セルの隣接関倸を考慮した市街地拡大因子，すなわち開発促 進，開発抑制と土地適性といった要因が取り入れられており，㴰澤 らのモデルでは, 住居・商業・業務といった用途系の状態量を導入 し，捕食者・被食者の生態学モデルの考え方により；用途間の需要

\footnotetext{
$*$ 金沢大学大学院自然科学研究科 准教授 $\cdot$ 博士 (工学)

Assoc. Prof., Graduate School of Natural Science \& Technology, Kanazawa University, Dr. Eng.

** 金沢大学大学院自然科学研究科 教授 · 工博

*** 福井県 修士 (工学)

**** 西松建設侏) 修士(工学)

Prof., Graduate School of Natural Science \& Technology, Kanazawa University, Dr. Eng. Fukui Prefecture, M. Eng.

Nishimatsu Construction Co., Ltd., M. Eng.
} 
循環や地域全体の影響も考慮している。これらの研究では, 比較的 簡単なルールで現実の都市の土地利用に類似した複雑なパターンを 再現できているといえる。しかし，既存研究では，メッシュやグリ ッドの空間データを扱う場合が多く，実際の土地利用活動のミクロ 的空間単位である宅地や街区などが殆ど研究対象とされていない.

本稿では，ミクロな土地利用の都市活動を再現するため，隣接宅 地間の相互作用を, 既存研究の CAの方法論を参考にして取り込み, 計画設計段階で設定した用途地域，前面道路などの計画設計条件の 影響, 宅地の幾何的特性の影響などを取り入れ，宅地単位での宅地 用途シミュレーションシステムを開発することを目的とする.なお， シミュレーションでは, 利用者の意思も重要であるが, 研究の初期 段階であるので，利用者の意思などはまだ考慮していない．

\section{2. 研究の方法}

本研究では， $\mathrm{CA}$ を用いたマクロな都市拡大シミュレーションの 既存研究の成果をミクロな市街地へと適用し, 計画設計条件の影響 を考慮するため，瀧澤らのモデルをべースにして計画設計条件パラ メータを追加している.

マクロな都市拡大シミュレーションでは，土地利用が連続的に生 起し，隣接セルが市街地化されていく．ミクロな場合, Erickson 他 は宅地と道路を, 道路網, 近傍宅地・街区の土地利用の影響を受け た一定のルールで成長させていくことを試みている．しかし，本稿 では，事業後の整理された区画における宅地用途の形成が目的であ り，ポリゴンである宅地の增殖と消滅がなく，事業地区内の宅地用 途の変遷がシミュレーションの対象となる.

$\mathrm{CA}$ を用いてミクロな宅地用途の変遷をシミュレーションするた め, 宅地用途の分類を住居・商業・工業・未利用地といった用途系で 行う。次に，宅地の用途系の形成には，各宅地が用途系の状態量を 持つことにし, 状態量の変化により, 複数用途のうち 1 つの用途が現 れるものとする．これらの方法はマクロレベルで行われた瀧澤らの モデルと類似しているため，瀧澤らモデルをべースにして構築する ことにした. なお, 近傍宅地や近傍街区などの影響だけでなく, 研 究の目的に合わせて用途地域や道路網などの計画設計条件も宅地用 途の形成要因としてシミュレーションモデルに導入する.さらに, 実際の宅地の幾何的特性が宅地によって異なり, 計画設計条件の影 響を受ける程度が異なるので,シミュレーションでは,宅地の幾何的 特性である面積や形状を考慮する必要もある。

このため, 研究の方法として, 澈澤らのモデルを基に, これに計 画設計条件による影響と宅地の幾何的特性を加えることで, シミュ レーションを行う．シミュレーションモデルの検証には，仮想地区 一の適用によりモデルの挙動を分析し,さらにその有効性を実際の 事例地区によって検証する，具体的には，仮想地区を用いてシミュ レレションを行い，各種パラメータの変化に合わせて用途別宅地利 用率の挙動を分析して, 空間パターンの変動と合わせてモデルの有 効性と安定性を検討する．実際の事例への適用について，金沢市の 土地区画整理事業の施行地区を選定し，現実の宅地利用を再現する ためのパラメータを設定し，CA の研究に良く用いられる浸透モデル のクラスター手法 ${ }^{11}$ によってシミュレーション結果と現実との空 間パターンの類似性を検証する. 最後に現実と異なるシナリオを設 定してシミュレーションを行い, シナリオの比較を通して計画設計
条件パラメータによる計画案の検証可能性を提示する.このような モデルによって，住民への事業の説明や縋覧が必要となる事業の遂 行のために,わかりやすい視覚的な資料として提示することができ， 専門知識に詳しくない住民の参加を支援できると考えられる.

\section{3.ミクロな宅地用途シミュレーションに用いるCAの基本概念}

\section{(1) 宅地用途}

シミュレーション用途は，細分すればより実際の市街地における 宅地用途の変化に近づくが，本研究では，細分類を行うにはより複 雑な条件を設定する必要があるため, 用途系として住居, 商業, 工 業，未利用地，公共的用途の $5 つ に$ 分類した. 公共的用途に関して は公園, 病院, 学校などその後の変化が起こりにくいもので, 都市 計画決定され得るものでもあり，シミュレーションには組み込まな いこととする.

（2）近傍宅地と多階層の隣接関係

街区内において，図1のように当該宅地の隣接宅地を近傍宅地と する.ミクロな都市空閒を扱うには, 街区内の近傍宅地だけに限定す ることは範囲が狭すぎる.このため, 多階層な隣接関係として, 宅地 レベルから街区レベルまで市街地全体を扱える近傍概念が必要であ る．街区レベルについては，当該宅地が存在する街区と道路中心線 を共有する街区を近傍街区としてその影響も取り入れることとした． 本研究では, 多階層の隣接関係を仮定して進めているが, 本稿では, 街区内の宅地及び街区レベルの隣接関係を扱うようにしている.
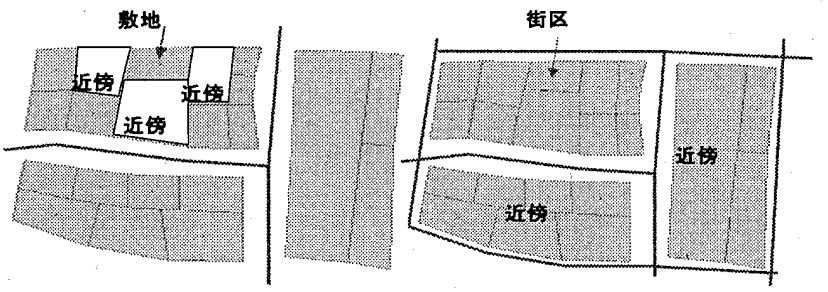

図 1 多階層な近傍関係

（3）初期用途・初期状態量とシミュレーションステップ

CA を用いた手法では，隣接関係に基づいて宅地用途をシミュレー ションするので，初期用途がないと遷移ルールを適用しても同じこ との繰り返しとなる。本稿では，土地区画整理事業施行後の宅地用 途の形成についてシミュレーションを想定しているため，初期用途 は，全て未利用地とする，そして，宅地の所有者や利用者の意思を 代表させるためには，乱数などを用いて用途別の初期状態量を与え るなどの考慮が必要である。 ‘具体的には，宅地用途が未利用地であ ったとしても，その宅地には，住居，商業，工業の状態量を有して いると考え，0〜1の一様乱数を用いて，それを初期状態量とする. 土地区画整理事業後における市街地形成は長い期間を要する場合 が多く,ここでは 1 年を 4 期とし, 25 年まで合計 100 回のシミュレ ーションステップを行うこととする.

\section{（4）遷移ルール}

1 つの宅地は, 用途別（住居・商業・工業）の状態量をそれぞれ持 つ. 状態量とは，それぞれの用途へのなりや寸さを示す宅地が持つ 潜在的なポテンシャルとして考えている。ある宅地内部の状態量の 総和が大きいということは，その宅地の土地利用が顕在化している ことを意味し，また，ある用途の状態量が他の用途の状態量よりも 
高ければ，その宅地はその用途が形成していると解釈できる，そこ で，瀧澤らのモデルを参考にして遷移ルールを設定する.

a) 用途形成

宅地内部の状態量の総和が闇值 $\mathrm{X}_{\max }$ より大きい場合には，その宅 地は土地利用が顕在化していると考え, 住居, 商業, 工業のいずれ かの用途を持つものとする. その際, 宅地内部の状態量のうち最も 大きいものがその宅地の用途として表れるとする.

b) 未利用地化

宅地内部の状態量の総和が閾值 $X_{\min }$ より小さい場合には, その宅 地は利用されなくなり，未利用地となる。

c) 現状維持

宅地内部の状態量の総和が閥值 $X_{\text {min }}$ 以上 $X_{\max }$ 以下であるならば, その宅地用途は変化せず, 前シミュレーションステップの宅地用途 と同じものとなる.

\section{（5）遷移ルールにおける計画設計条件と幾何的特性の影響}

ミクロな市街地では, 用途地域や前面道路などの計画設計条件と 宅地の幾何的特性が宅地用途の形成に影響があることから，ミクロ な宅地単位での用途の形成要因として新たに取り入れる必要がある. 本稿では, 宅地用途の遷移ルールとしては, 近傍宅地, 近傍街区だ けではなく, 計画設計条件と宅地の幾何的特性も考慮する. 以上の基 本的構想に基づいて, 次の節では, 瀧澤らのモデルを参考にしてシ ミュレーションモデルを構築する.

\section{4. シミュレーションモデル式}

シミュレーションモデルの式(1)は瀧澤らのモデル式を参考にし て作成したものである．新しく取り入れたのは，用途地域や前面道 路などの計画設計条件と宅地の幾何的特性による影響量である.

$$
\begin{aligned}
& x_{i}^{(m)}(t+1)=\left\{x_{i}^{(m)}(t)+\Delta x_{i}^{(m)}(t)+\Delta x_{b}^{(m)}(t)\right. \\
& \left.+\operatorname{Metab}_{i}^{(m)}(t)+\text { GloTransp }{ }_{i}^{(m)}(t)\right\} \cdot\left(\frac{1}{3} \sum_{j=1}^{3} P_{j}^{(m)}\right)^{q} \\
& x_{i}^{(m)}(t) \text { : 宅地 } \mathrm{i} \text { のステップ } \mathrm{t} \text { における用途男の状態量 } \\
& m: \text { 用途 }(R=\text { 住居、 } C=\text { 商業、 } I=\text { 工業 }) \\
& t: \text { ステップ } \\
& i \text { : 対象宅地の番号 } \\
& b: \text { 対象宅地の存在する街 区の番号 } \\
& P_{j}^{(m)} \text { : 用途甶の計画設計条件 パラメータ } \\
& q \text { : 宅地の幾何的特性によ る計画設計条件補正係 数 } \\
& M e t a b_{i}^{(m)}(t) \text { : 用途転換の循環状態量 } \\
& \text { GloTransp } i_{i}^{(m)}(t) \text { : 地区全体の影響状態量 }
\end{aligned}
$$

式(1)はシミュレーションの $t+1$ 時点における, 当該宅地 $i$ の用途 $\mathrm{m}$ の状態量を計算する式である. $\mathrm{t}+1$ 時点の状態量を, $\mathrm{t}$ 時点の状態 量に, 宅地 $\mathrm{i} に$ 隣接する近傍宅地, 近傍街区の影響量, 宅地内部の 状態循環, 地区全体の影響量, 用途地域や前面道路などの計画設計 条件と宅地の幾何的特性による影響量を取り入れることによって表 している。

式 (2)，(3) は近傍宅地・街区の土地利用からの影響を受けて, 状 態量の増減を考慮するものである.近隣宅地の影響を計算する式 (2) は瀧澤らのモデルを利用した．近傍宅地・街区の状態量の平均を求 め, 当該宅地, 当該宅地の存在する街区の状態量との差を出すこと により，近傍の土地利用の影響を考虑した状態量を表すことができ ると仮定する，ここで，街区の状態量とは，街区に存在する宅地の 状態量の平均であると定義している.

$$
\begin{aligned}
& \Delta x_{i}^{(m)}(t)=G^{(m)} \cdot\left\{\frac{1}{N_{i}} \sum_{k=1}^{N_{i}} x_{k}^{(m)}(t)-x_{i}^{(m)}(t)\right\} \\
& k \text { : 近傍宅地の番号 } \\
& G^{(m)} \text { : 用途 } m \text { の近傍宅地による変化 補正保数 } \\
& N_{i} \text { : 宅地门近傍宅地数 } \\
& \Delta x_{b}^{(m)}(t)=G^{(m)} \cdot\left\{\frac{1}{N_{b}} \sum_{l=1}^{N_{b}} x_{l}^{(m)}(t)-x_{b}^{(m)}(t)\right\} \\
& l \text { : 近傍街区の番号 } \\
& G^{(m)} \text { : 用途 } m \text { の近傍街区による変化補正係数 } \\
& N_{b} \text { : 街区bの近傍街区数 } \\
& \operatorname{Metab}_{i}^{(m)}(t)=\frac{D^{(m)} \cdot x_{i}^{(m)}(t) \cdot x_{i}^{(m+)}(t)}{1+H \cdot x_{i}^{(m+)}(t)} \\
& -\frac{S^{(m)} \cdot x_{i}^{(m)}(t) \cdot x_{i}^{(m-)}(t)}{1+H \cdot x_{i}^{(m)}(t)} \\
& m+\text { : 用途 } m \text { の状態量を増やす用途 } \\
& m-: \text { 用途 } m \text { の状態量を減らす用途 } \\
& D^{(m)}: \text { 状態量流入パラメータ } \\
& S^{(m)}: \text { 状態量流出パラメータ } \\
& H \text { : 状態量の増加速度抑制》調整パラメータ }
\end{aligned}
$$

式 (4) は，瀧澤らのモデルを利用したものであるが，用途転換の 傾向を宅地内部の状態循環注1)で表したものとして異なる意味を持 つ. 状態循環は 3 つ状態量がお互いに影響しあうことで, 用途転 換の可能な傾向が表れると仮定する. 用途転換の可能なパターンは 多様であり，利用者の意図にも関わる，例えば，工業 $\rightarrow$ 住居 $\rightarrow$ 商業 のような循環パターンの場合, 工業から住居, 住居から商業へ用途 転換の傾向になり, 住居の状態量の計算は, 工業の状態量から流入 し, 商業の状態量へ流出するものになっている. パラメータ $\mathrm{D}^{(\mathrm{m})}$ と $\mathrm{S}^{(\mathrm{m})}$ は, 用途転換の傾向をコントロールする役割を持っている．H は状態量の流入や流出量に抑制するために設けている，循環パター ンが多くあるため，シミュレーションを簡略化するため，本稿では 一つの循環パターンを用いることとした。

$$
\begin{gathered}
\text { GloTransp }{ }_{i}^{(m)}(t)=\frac{G T^{(m)} \cdot x_{i}^{(m)}(t) \cdot \frac{X^{(m)}(t)}{N_{a l l}}}{1+H \cdot \frac{X^{(m)}(t)}{N_{a l l}}} \\
G T^{(m)}: \text { 用途 } m \text { の地区全体の調整パラメータ } \\
N_{a l l}: \text { 画地総数 } \\
X^{(m)}(t): \text { 時刻 } t \text { における用途 } m \text { の状態量の総和 } \\
H: \text { 状態量の増加速度抑制の調整パラメータ }
\end{gathered}
$$

式（5）は，澈澤らのモデルを利用したもので，地区全体の影響を 表す注2)、影響量は考慮している宅地内部の状態量に依存し，それと 地区全体のその用途の状態量の平均值との積で表れることと仮定す る. 状態量の大きな宅地ほど多くの影響があることになるが，その 増加速度は地区全体の当該用途の平均状態量が大きいほど制約を受 ける.

式(6)では, 新しい内容として, 計画設計条件による影響として用 途地域, 前面道路及び角地非角地による影響をここで考虑する.シ ミュレーションを通じて, 宅地用途の変遷を表現させるために, 計 画設計条件の影響を実数值で表すこととする.

まず, $P_{1 u}{ }^{(m)}$ は, 用途地域 $\mathrm{u}$ における用途mの状態量を調整する役 割をするものとして与える. そして，前面道路種別，角地非角地に よる影響を考虑する $\mathrm{P}_{2 \mathrm{r}}{ }^{(\mathrm{m})}, \mathrm{P}_{3 \mathrm{c}}{ }^{(\mathrm{m})}$ を与える。これら 3 つの計画設計 条件 $P_{j}{ }^{(m)}$ を各宅地の特性とする.

マニルザマンらは宅地用途の転換と宅地の幾何的特性との関連を 分析し，宅地形状がどれだけ整っているのかを示す Compactness 
Index（C. Index，式（7））という宅地面積と周長を用いた指標注 3) を提案している. この指標は宅地の形状を示す, 宅地面積と周長を 用いた無次元の指標である.c $\mathrm{c}$ 完全な円の時に值が 1 となり，も っとも宅地形状が整っているとしている $(0<\mathrm{c}<1)$ ．c の值が小 さいということは, 宅地形状が複雑であるということである.また， 沈らの研究では, ある宅地の宅地形状が不整形で複雑な場合, 宅地 の利用が制限され，計画設計条件による影響が反映されにくいとい うこと注4)を指摘している.

$\sum_{j=1}^{3} P_{j}^{(m)}=P_{1 u}^{(m)}+P_{2 r}^{(m)}+P_{3 c}^{(m)}$

$P_{j}^{(m)}:$ 用途mの計画設計条件パラメータ

$j:$ 計画設計条件数 $3(1=1 u, 2=2 r, 3=3 c)$

$P_{1 u}^{(m)}:$ 用途地域パラメータ

$P_{2 r}^{(m)}:$ 前面道路パラメータ

$P_{3 c}^{(m)}:$ 角地非角地パラメータ

$u$ : 用途地域の種類

$r$ : 前面道路の種類 $(1=$ 幹線道路、 $2=$ 補助幹線道路、 $3=$ 区画道路 $)$

$c$ : 角地の種類 $(1=$ 角地 $、=$ 非角地 $)$

$c=2 \frac{\sqrt{\pi a}}{p}$

$c:$ Compactness.Index

$p$ : 周長

$a$ : 宅地面積

c の取り入れ方については, 計画設計条件補正係数として $\mathrm{q}=\mathrm{c}^{2}$ を 計画設計条件パラメータ $\sum_{j=1}^{3} P_{i}^{(m)}$ に指数として用いることによっ て, $\left(\frac{1}{3} \sum_{j=1}^{3} P_{j}^{(m)}\right)^{q}$ 全体で計画設計条件による規制・誘導の影響の程度 を考慮した宅地の幾何的特性による影響量と考えることとする.

\section{5. モデルの挙動分析}

本節では, 用途 $\mathrm{m}$ の変化補正係数 $\mathrm{G}^{(\mathrm{m})}$, 状態量流入パラメータ $\mathrm{D}^{(\mathrm{m})}$, 状態量流出パラメータ $\mathrm{S}^{(\mathrm{m})}$, 状態量の増加速度抑制の調整パラメー タ $\mathrm{H}$, 用途 $\mathrm{m}$ の地区全体の調整パラメータ $\mathrm{GT}^{\mathrm{m}}{ }^{\mathrm{m})}$, 計画設計条件パラ メータ $\mathrm{P}_{j}{ }^{(\mathrm{m})}$, 遷移ルールの閾值 $\mathrm{X}_{\max }, \mathrm{X}_{\min }$ を変化させることにより, 用途形成とその変遷に関してモデルの挙動を分析する. 考察の対象 は，シミュレーションにおける用途別宅地利用率である.

\section{（1）仮想地区における初期状態量の設定とモデルの安定性}

まず，宅地形状が規則な地区で行い，パラメータの挙動を分析す る. そこで, $c=0.89$ となる正方形の宅地が構成する単純なグリッ ドを元に作成した仮想的な地区（図 2）で行うこととする，道路網 を無くせば，普通のグリッドの 2 次元 CA モデルとして理解できる. また, 各宅地の用途別の初期状態量は $0 \sim 1$ の一様乱数を用いて与え た.さらに,パラメータを変化させた際に，モデルの挙動が明確に 考察できるように，異なる用途系でも同じ值を用いて，ベースとす るパラメータセット（表 1）を設定する．それを元に，影響をみる パラメータのみを大小変化させ，それぞれ 100 回の初期乱数による シミュレーションを行い，用途別宅地利用率の変動をみる。 ベース とするパラメータセットを用いたシミュレーションは 25 年に相当 する 100 ステップまで行い, 結果を図 3 に示す.このようなステッ プの時間設定により，パラメータを用いて市街地形成のプロセスを コントロールする，パラメータを変化させたシミュレーションの挙
動分析は図 4 に示す.

モデルの安定性の検証には, ベースとするパラメータセットを用 いて，一様分布の初期乱数によるシミュレーションを 100 回行い, 宅地利用率の平均とその標準偏差を用いた誤差範囲を図 3 に示し, 宅地利用率の不偏分散を用いて正規分布の母平均信頼区間を推定し, 各ステップの平均はすべて有意水準 0.05 で有意が認められた. 同じ パラメータを用いたので，各ステップの異なる用途系の宅地利用率 も重なるようにみえる，なお，住居・商業・工業の間には変動があ り，標淮偏差の最大值が $8 \%$ まで上っているが，未利用地について， 最初 25 ステップと最後の 25 ステップは殆ど変動がない。 パラメー 夕を変化させた場合も，同じように有意性が認められたので，より 明確にパラメータの変化による宅地利用率の変動を表現するため, 図 4 にはシミュレーションの平均と標準偏差を用いた誤差範囲では なく,ひとつのシミュレーションの結果を示すようにした.
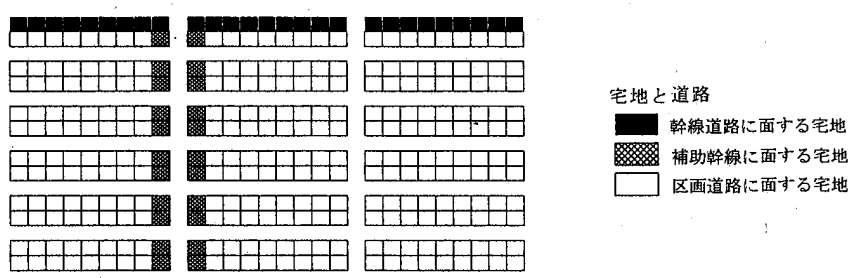

図 2 挙動分析を行うための仮想地区

表 1 挙動分析時にベースとしたパラメータセット

\begin{tabular}{|c|c|c|c|c|}
\hline & $\mathrm{R}$ (住居) & $\mathrm{C}$ (商業) & $I$ (工業) \\
\hline 角途地域 & p1:淮工業 & 1.0000 & 1.0000 & 1.0000 \\
\hline \multirow{3}{*}{ 前面道路 } & p21:幹線道路 & 1.0000 & 1.0000 & 1.0000 \\
\hline & p22: 補助幹線道路 & 1.0000 & 1.0000 & 1.0000 \\
\hline & p23:区画道路 & 1.0000 & 1.0000 & 1.0000 \\
\hline \multirow{2}{*}{ 角地·非角地 } & p31:角地 & 1.0000 & 1.0000 & 1.0000 \\
\hline & p32：非解地 & 1.0000 & 1.0000 & 1.0000 \\
\hline \multirow{2}{*}{ Metab項 } & D:状能量流入パラメータ & 0.0100 & 0.0100 & 0.0100 \\
\hline & S:状態量流出パラメータ & 0.0100 & 0.0100 & 0.0100 \\
\hline GloTransp項 & GT：地区全体の調整パラメータ & 0.0500 & 0.0500 & 0.0500 \\
\hline $\mathrm{H}:$ 获態 & 㩖の增加速度师制の調整パラメータ & \multicolumn{3}{|c|}{1.0000} \\
\hline \multicolumn{2}{|c|}{ G：近傍宅地・街区に上る変化補正係数 } & 1.0000 & 1.0000 & 1.0000 \\
\hline
\end{tabular}

\begin{tabular}{|l|l|l|}
\hline 閥值 & $X(\min )$ & 0.00 \\
\cline { 1 - 2 } & $X(\max )$ & 4.00 \\
\hline
\end{tabular}

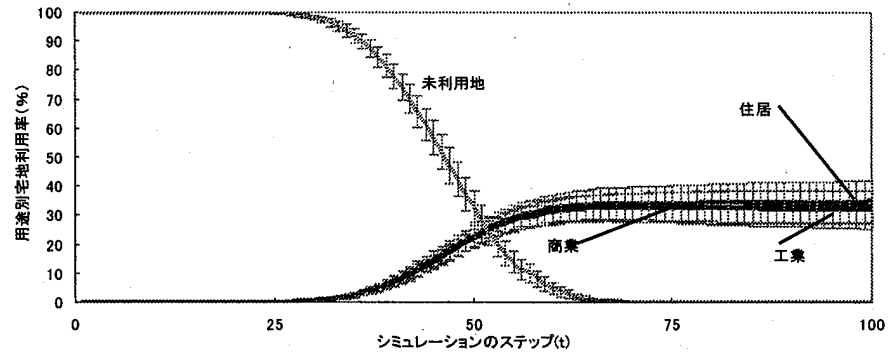

図 3 シシュレーションの宅地利用率の平均と標準偏差を用いた誤差範囲

\section{（2）計画設計条件パラメータと闒値の挙動}

図 4(1-a, 1-b)のように, 住居の用途地域パラメータ $\mathrm{P}_{1 \mathrm{u}}{ }^{(\mathrm{R})}$ を変化 させた場合であるが，大きくすれば住居の宅地利用率が増加し，小 さくすれば住居の宅地利用率が隇少することが分かる.このように, 用途 $\mathrm{m}$ のパラメータを調整すれば，用途 $\mathrm{m}$ の宅地利用率が増減する という傾向は，用途地域のパラメータ以外，他の計画設計条件パラ メータ $\mathrm{P}_{\mathrm{j}}{ }^{(\mathrm{m})}$ （前面道路, 角地・非角地）についてもみられる.

遷移ルールの間值 $X_{\max }$ を変化させた場合 (図 4 の 2-a と 2-b) であ るが，当然ではあるが閥值を大きくすれば用途の発生が遅くなり， 小さくすれば用途の発生が早くなっていることが分かる. 


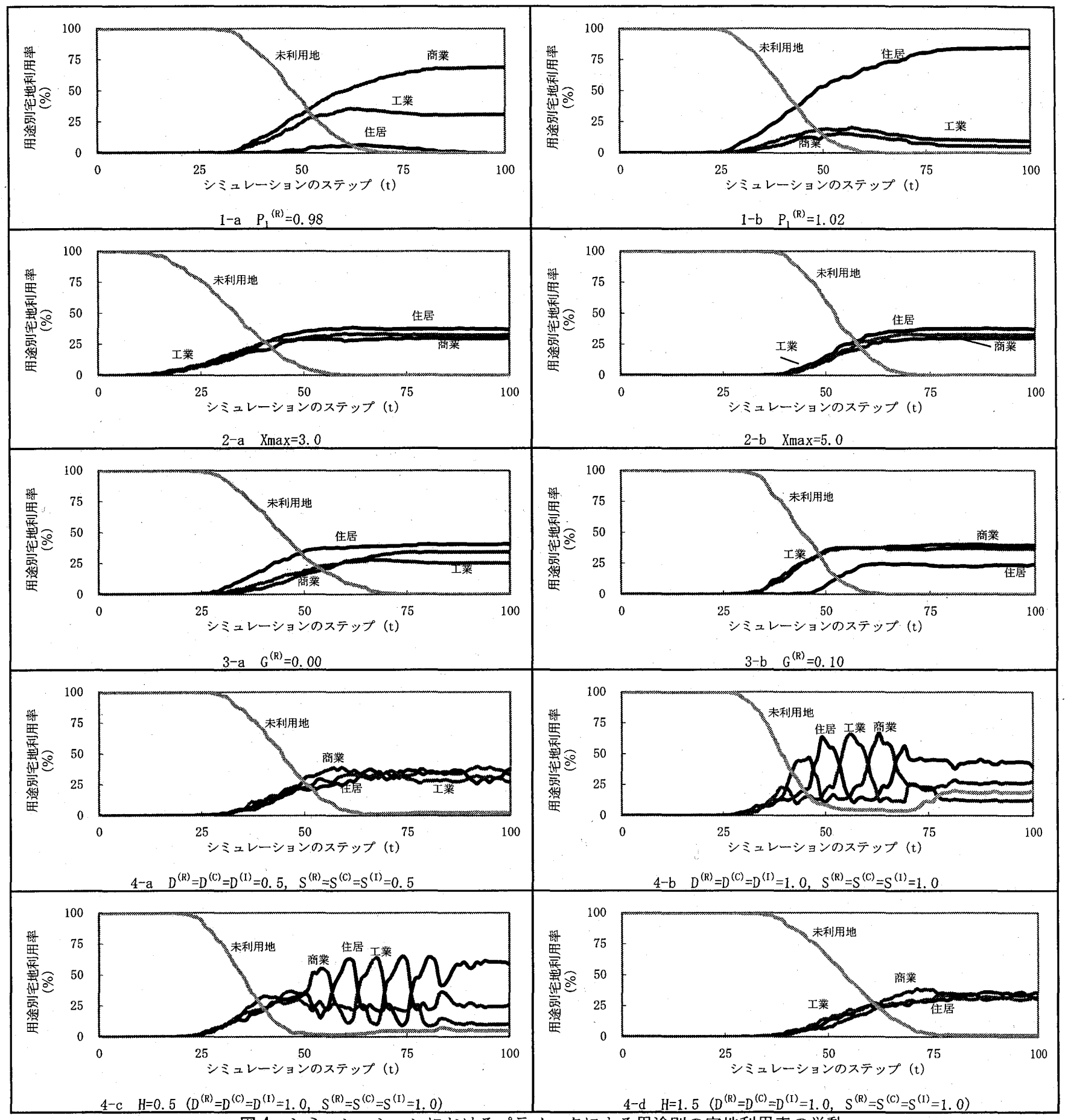

図 4 シミュレーションにおけるパラメータによる用途別の宅地利用率の挙動

（3）近傍の影響について

$\mathrm{CA}$ の基本である近傍の影響は重要である. 住居以外の変化補正係 数 $G^{(m)}$ を 1 にし，図 4(3-a，3-b)のように, $G^{(R)} 0$ から 0.1 に変化 させたが, 0 の場合, 近隣から影響がなく, $G^{(R) を ~} 0.1$ にした場合, 近隣の影響で, 住居の宅地数の減少が見られた。これは, 式(4)によ れば，住居の近傍状態量との差がプラスかマイナスの場合により影 響が異なり，住居の状態量の增加も減少も起こりえるということで ある。

（4）宅地内部の状態循環と地区全体のパラメータの挙動

住居, 商業, 工業の状態量流入パラメータ $\mathrm{D}^{(m)}$, 状態量流出パラ

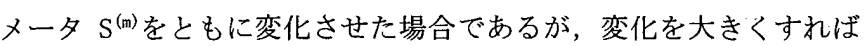

宅地用途の循環（図 4 の 4-a と 4-b)が表れる. しかし，単独で調整 する場合，パラメータ $\mathrm{D}^{(\mathrm{m})}$ を大きくすれば，単に用途 $\mathrm{m} の$ 宅地利用

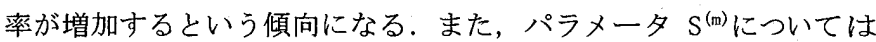
逆の傾向が見られる．状態量の増加抑制パラメータ H は，宅地内部 の影響をコントロールでき，值が大きく設定されると，循環による 用途 $\mathrm{m}$ の宅地利用率の振動の幅が小さくなる(図 4 の 4-c と 4-d). そして，H は地区全体への影響もあり，大きく設定すると，用途 $\mathrm{m}$ の宅地状態量の増加が抑制される. 用途 $\mathrm{m}$ の地区全体の調整パラメ 一タ $\mathrm{GT}^{(\mathrm{m})}$ については，大きく設定すれば，用途 $\mathrm{m} の$ 宅地利用率が増 加する傾向がみられる，他に，シミュレーションのステップの増加 につれ，近隣による状態量の変化が宅地内部による状態量の変化に 
比べて大きくなるので, 図 4(4-b，4-c) のように用途転換の現象も なくなり，用途別の宅地利用率が安定する．用途転換を長くさせる ことが必要ならば， $\mathrm{D}^{(\mathrm{m})}$ や $\mathrm{S}^{(\mathrm{m})}$ を大きく設定することで効果がある.

このように, シミュレーションの時間経過と共に, 計画設計条件 のパラメータ, 宅地内部の状態循環や地区全体のパラメータは複雑 な市街地成長のプロセスとの因果関係があることがわかった．補足 として，図 2 の仮想地区の宅地は，道路網を無くせば，道路側の宅 地がお互いに隣接していないが， CA の浸透モデルのセルとしてみ ることができる，さらに状態量についてみると，シミュレーション のステップの増加につれ宅地用途 $\mathrm{m}$ の状態量が大きくなり, 分散も 大きくなり，居所の近隣同士の状態量は均等化の傾向がみられ，自 己組織化の役割を果たし，宅地用途の空間パターンに影響を及ぼし ている. 多くのCA 関連研究で既に解明されているように，浸透確率 が同じであれば，クラスターのパターンも類似する.すなわち，シ ミュレーションでは, 特定用途の一定の宅地利用率が形成された場 合，空間分布では当該用途のクラスターの大きさや数も類似する. ここでいうクラスターは，同じ用途で隣接し合う宅地の群であり， クラスターの大きさは一つのクラスターにある宅地数である. 図 5 では, 100 パターンの初期乱数によるシミュレーションの 100 ステ ップ目の結果を示しており，クラスター数が 1 の場合には，標準偏 差が多少大きくみえるが，他は小さくなっている．シミュレーショ ンの結果(図 3)として用途系別の宅地利用率がほぼ重なり，図 5 に も用途別のクラスターの大きさと数が類似することを確認できた. 次節で非規則的宅地を対象にシミュレーションの結果と事例地区の 空間分布との比較によってこの現象を検証することもできる.

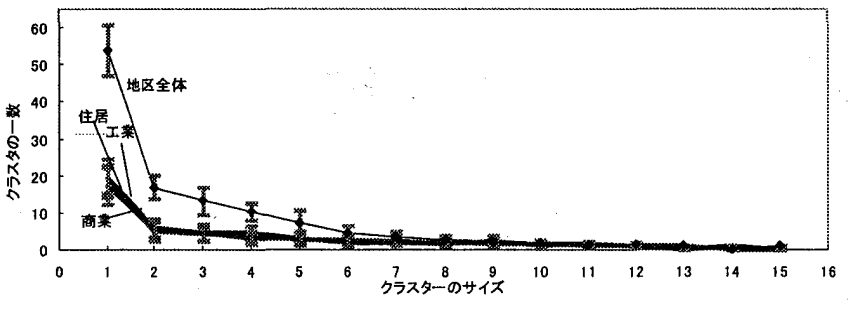

図 5 乱数によるシミュレーションの空間パターン

\section{6. 事例によるモデルの検証}

\section{(1) 事例地区の選定}

モデル検証のために, 土地区画整理事業施行後の宅地用途の形成 に注目して金沢市の土地区画整理事業を対象に事例として取り上げ, 事例地区の選定を行う.シミュレーションの可能性を検証するため, 多くの用途を許容できる用途地域を検証の対象としたい，なお，道 路網については, 前面道路として幹線道路, 補助幹線道路および区 画道路があることを選定基準とする。

以上の選定基準により抽出作業を行った結果，松村第一地区 （施行年度 1969〜73）の一部であるが，主要地方道金沢・港線を含 み，多用途の利用が可能である準工業地域がかけられている事例 地区を対象とした．この地区は，松村第一地区でも最も用途の混在 がみられる地区であり，図 6 に指定用途地域を示している，同地区 の区画整理事業は, 図 7 のうに 1969 年から 1992 年の時点まで, 表 3 に示寸用途別宅地利用率で市街地が形成されている.

（2）パラメータの設定とシミュレーション
準工業地域は，主に軽工業やサービス施設等が立地する地域であ り，危険性・環境悪化が大きい工場のほかは，ほとんど建てられる. このため, 他の用途地域に比べると, 比較的に偏らないパラメータ

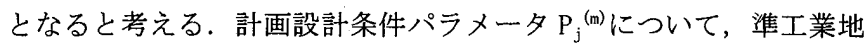
域の各用途のパラメータを 1 にする．幹線道路沿いには商業が立地 しやすく，区画道路沿いには住居が立地しやすいということで，前 面道路のパラメータを表 2 のように調整した．角地に商業が立地し やすく，非角地に他の用途が立地しやすいということで，角地のパ ラメータを表 2 のように調整した，まだ準工業地域なので，工業系 のパラメータを住居よりやや高くした。

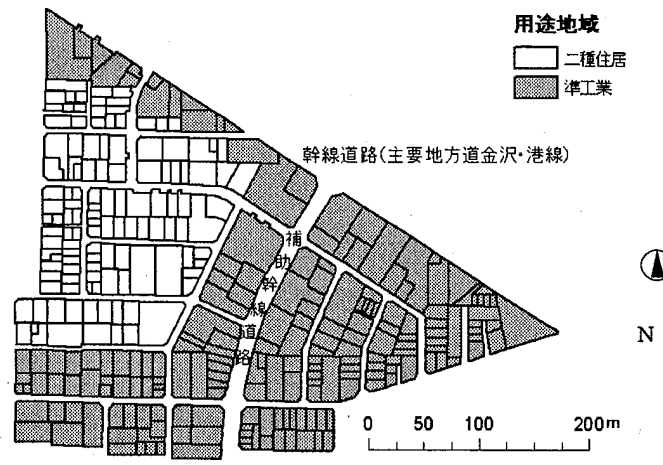

図 6 松村第一地区の宅地データ (淮工業地域) 表 2 シミュレーション時のパラメータの值

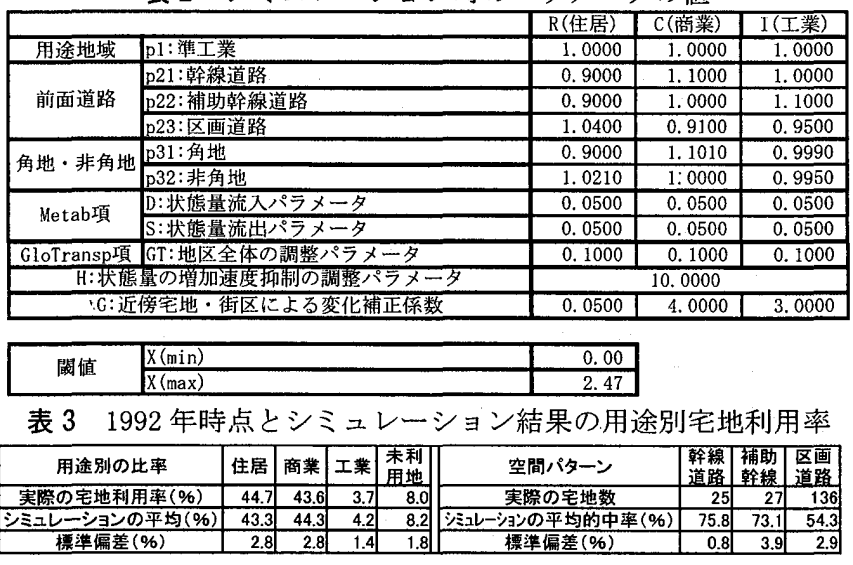

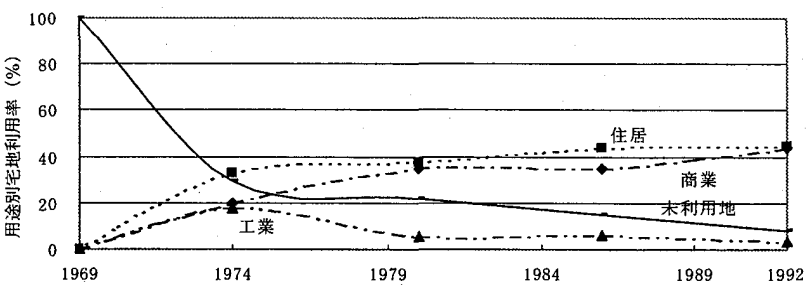

図7事例地区における宅地用途の形成

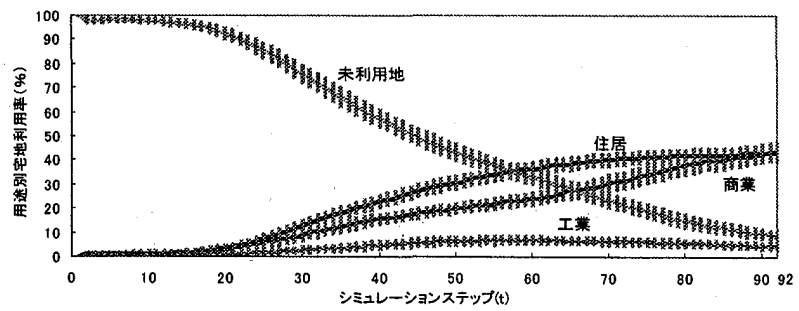

図8 シシュレーションの宅地利用率の平均と標準偏差による誤差範囲

なお，図7に示す23年の宅地用途の形成を再現するため, 計画設計 条件以外のパラメータ(表2)も調整した. まず, 状態循環 $D^{(m)}, S^{(m)}$ とH 
のパラメータについては, 微妙な増减も用途循環の周 期と振幅に大きく影響するが, 事例地区では用途転換 があまりみられないので, $\mathrm{D}^{(\mathrm{m})}, \mathrm{S}^{(\mathrm{m})}$ を小さく調整し, H を大きく調整した. 次に, $\mathrm{GT}^{(\mathrm{m})}$ の微妙な増減も地区全 体の用途mの状態量に大きく影響するので, 宅地用途 の形成プロセスに合わせて小さい值にして調整した. 最後, 計画設計条件のパラメータにより, 商業と工業 の状態量が大きい宅地が実態以上に多かったので, $G^{(\mathrm{C})}, G^{(\mathrm{I})}$ を大きくして状態量を減らす必要があった.

初期乱数によるシミュレーションでは，図8に示す ように，事例地区における用途形成の 23 年に合わせて 92ステップを行ったところで, 1992年までの実際の宅 地利用率の変化を比較すると, 各用途の変遷傾向が非 常に似ているといえる. 表3より, 100回シミュレーションの用途別 宅地利用率の平均については, 住居・商業・工業の差が殆どなく, ほぼ再現することが出来ている. なお, 実際の宅地用途の場所を比 較し, 100回シミュレーション(表3と図9)では, 幹線道路と補助幹線 沿いの宅地用途の平均的中率は75\%前後になり，区画道路沿いの的 中率も半数以上になっているので, 空間パターンの再現性も非常に 高いといえる. なお, 用途別宅地利用率や的中率の標準偏差が $4 \%$ 以 内なので, シミュレーションは非常に安定しているといえる.

しかし, 事例では, 宅地用途がもっと早い時期で発生し, 宅地利 用率が複雑な挙動を示すが，シミュレーションは，これを精度高く は再現できなかった。これは，今回のシミュレーションプロセスで は, 状態循環のパラメータを固定して変化させないシステムを用い ることから生じる問題で, 今後, 用途転換のパターンや状態循環の パラメータを事例地区の状況に合わせて変化させるシステムとする ことにより，実際の宅地用途変遷プロセスにあわせてシミュレート することも可能と考えられる. 補足であるが, 事例地区では, 宅地 形状に関する $\mathrm{c}$ 值の 2 乗は $0.35 \sim 0.78$ の範囲となっており, 表 2 の計画設計条件パラメータ $\mathrm{P}_{\mathrm{j}}^{(\mathrm{m})}$ がもたらした状態量の変化は 0.94 〜 1.06 倍の範囲となる.

表 4 クラスターを用いた空間分布パターンの比較

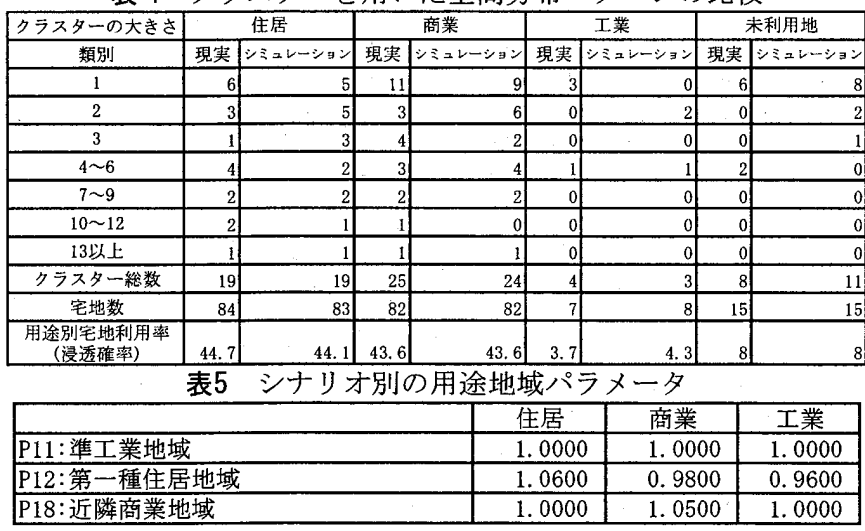

\section{（3）空間分布パターンの検証}

前面道路別によるシミュレーションの的中率を検証したが，より 具体的に空間パターンを検証するため, 100 回シミュレーションか らランダムに一回を抽出した．空間分布パターン（図 9）について みると，現実の宅地用途の分布と類似していると考えられる. シミ ュレーション結果と事例地区について, 宅地用途の空間分布パター

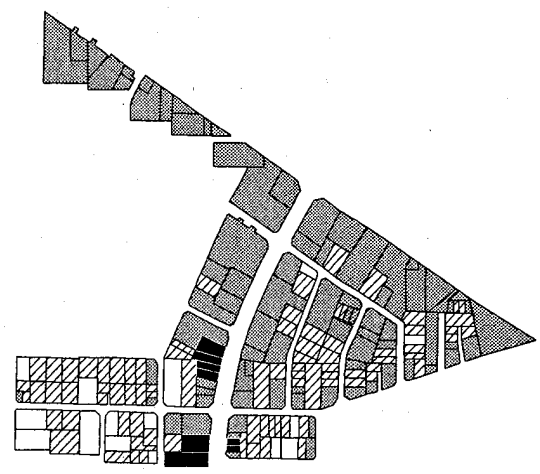

$\square 7$ 住居

シミュレーション宅地用途 (92 ステップ目)
図 9 空間分布の比較

ンの類似性を評価するために, CA の研究に良く用いられる浸透モデ ルのクラスターの方法によって, 浸透確率すなわち用途別宅地利用 率, 同種類用途の塊すなわちクラスターから検証する.

用途別の宅地利用率を浸透確率として考えると, 現実とシミュレ ーションでは，類似する宅地利用率があれば，類似する浸透確率が あるので,類似するクラスターが形成されるはずである.表 4 より， シミュレーションの結果と現実と比べ, 宅地数とクラスターの大き さやその度数分布の傾向はほぼ一致していることが分かる。このよ うに，クラスターの大きさの度数分布を用いてシミュレーションの 有効性も確認できた。

以上より, 宅地利用率, 空間分布などでは, 現実とシミュレーシ ヨン結果が類似しているという結果が得られた。このため, 事例地 区では，CA を用いたシミュレーションモデル式やパラメータの值は 有効といえる. 次の節では, 図 9 の空間パターンに用いられた乱数 を用いてシナリオ分析の可能性を検証したい. .
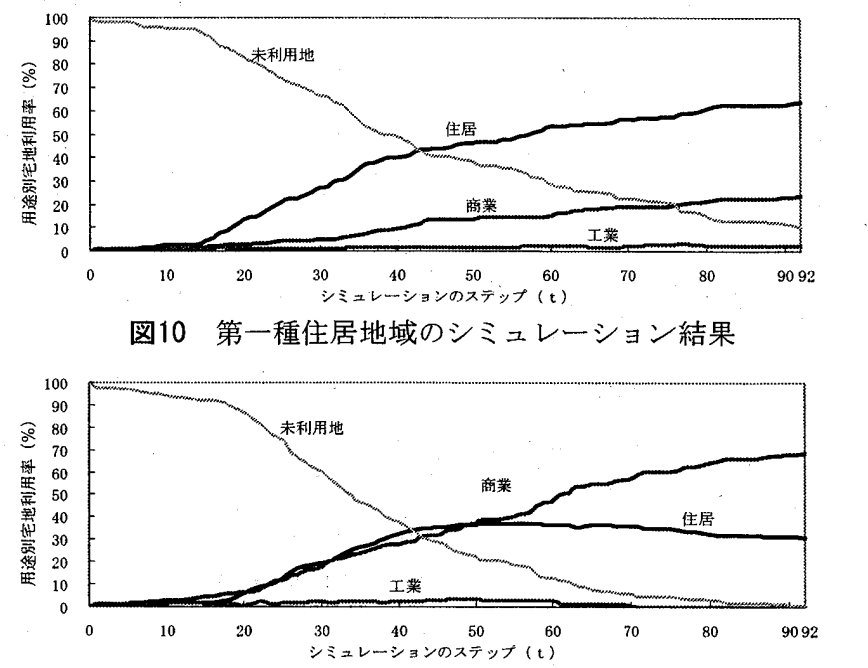

図11 近隣商業地域のシミュレーション結果

\section{7. シナリオ分析の可能性一事例地区における用途地域の検証}

本節では現実とは別のシナリオを設定し, シミュレーションを行 う.すなわち, 計画段階において, 事例地区を別の用途地域で設計 した場合の将来市街地像としての宅地利用率を検証してみたい.

このため, 表 5 のように, 前面道路や角地のパラメータを変更せ ず，用途地域だけを変更することで，別のシナリオとする，第一種 住居地域のシナリオでは，これまでは危険性，環境悪化が大きい工 
場のほかは，ほとんどが建てられる準工業地域であった ものを，住居の環境を守るために第一種住居地域へと変 更し, 表 5のように住居のパラメータの值を大きくする. 近隣商業地域のシナリオでは，準工業地域を近隣商業地 域とし，商業のパラメータの值を大きくする.シミュレ ーション結果を図 10１2 に示す.第一種住居地域のシナ リオの場合, 用途地域が準工業地域であったときよりも， 住居の用途別宅地利用率が増加し, 商業, 工業の用途別 宅地利用率が減少しているため, より住環境が守られて いる結果となっている.近隣商業地域のシナリオの場合, 商業が大きく伸び，住居が半減し，事例地区では商業環 境が形成されているといる。 なお，図 12 では, シナリオ 別の空間パターンを示している.

なお，今回用いたパラメータは，事例地区においてのみ有効性を 検証したため, 今後多くの事例地区での学習を通して, 統計的に有 意なパラメータを確定できれば，計画設計段階で, 異なるシナリオ を設定し, 将来市街地像としての用途別宅地利用率をシミュレーシ ヨンで提示でき, 参加型の計画検討などに役立てると考えられる.

\section{8. 結論}

本研究では, 滝澤らのモデルを参考して, 宅地および街区レベル の隣接関倸を考慮した CA 用いたミクロなシミュレーションモデ ルを開発した.また, 宅地用途の形成要因には宅地内部の状態循環, 地区全体の影響, 宅地および街区の隣接関係の考虑だけでなく, 計 画設計条件による影響と宅地の幾何的特性による影響も取り入れた. シミュレーションの検証に用いられる仮想地区と事例地区において， 宅地の幾何的特性の制約を受けた計画設計条件の影響, すなわち用 途地域, 前面道路および角地非角地の影響はシミュレーションの結 果である用途別宅地利用率の挙動により確認できた. なお，他の用 途形成の各要因パラメータを変化させることで, ミクロな市街地に おける宅地用途シミュレーションにおいて, 用途別宅地利用率の举 動を分析し，シミュレーションモデルの有効性を検証した。さらに 初期乱数によるシミュレーションの安定性も統計的に検証した.

そして, 土地区画整理事業施行後の土地利用に着目して事例地区 を選定し,このシミュレーションモデルを適用した. その結果, 用 途別宅地利用率については現実の現象をほぼ再現することが出来て いる. また, 宅地用途別の空間分布パターンからみても, 実際の再 現性が高いことも分かった，さらに，事例地区の用途地域を準工業 地域から第一種住居地域や近隣商業地域へと変更したシナリオでシ ミュレーションを行った. その結果, 用途地域のパラメータを変更 することにより, 変更された用途地域に相応しいシミュレーション 結果が提示されたと考えられる. しかし, 複雑な宅地用途変遷プロ セスにあわせて精度高くシミュレートすることは課題として残って いる.

今後は, パラメータの設定について, 多くの事例地区での学習を 行い，さらに各用途地域のパラメータの值を統計的に検証すれば, 土地区画整理事業などの計画段階で, 市街地の将来像を宅地用途で 提示することが可能となると考えられる.

今後の課題として, 宅地所有者や利用者の意思や活動を反映させ るため, CA をベースとしたマルチェージェントシステムによるシミ

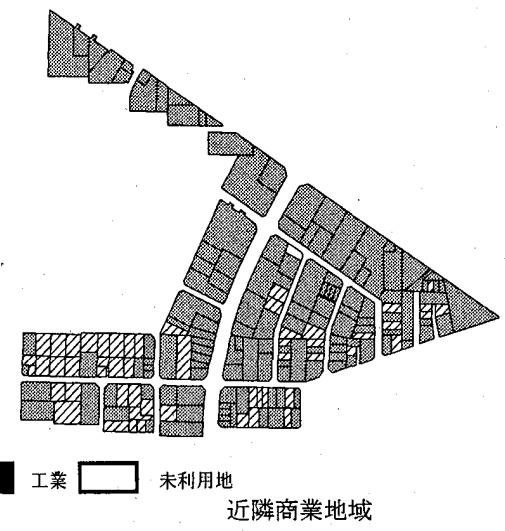

図 12 シナリオの比較

エレーションの方法論を導入し, エージェントの意思によって初期 状態量を与え, 空間パターンとの関倸を検証し, さらにシミュレー ションした宅地用途, エージェントの特性, 宅地の条件によって用 途の細分類を行い，居住人口もしくは雇用人口を算出し，建物の形 態を決定することで, 地区レベルの景観シミュレーションの可能性 も検討することがあげられる.さらにエージェントの宅地単位のエ ネルギー消費や車の利用などによって地区レベルの環境評価を試み たいと考えている.

謝辞 : 本研究は科学研究補助金基艋研究 C(課題番号 19560613)の補助を受け ている.ここで記して感謝の意を表す。

注

注 1)瀧澤らのモデルでは, 経済循環という用語を用いて, セル内において土 地利用の需給の変化を表している. それぞれの用途 $\mathrm{m}$ に対する $\mathrm{m}+$ からの需 要と $\mathrm{m}$-からの供給という経済循環があると考えられている。

注 2)瀧澤らのモデルでは, グローバルな流入という用語を用いているが，本 稿では，都市全体の影響を考虑できず，シミュレーションの対象地区の影 響として地区全体の影響にした。

注 3) 参考文献 2)の 84 ページを参照する.

注 4) 参考文献 3)では, 土地区画整理事業前後における街区画地の幾何的特性 と用途地域の変容との因果関係を考察した.

\section{参考文献}

1)川上光彦・木谷弘司・上出邦弘: 土地区画整理事業施行区域における市街化 の実態一金沢市における組合施行の事例報告一, 都市計画学会学術研究論 文集第33号, pp. 145-150,1998.

2)K. M. マニルザマン・浅見泰司・岡部䉆行: 東京都世田谷区における画地の土 地利用とその形状に関する研究, GIS一理論と応用 Vol. 2, No. 1, pp. 83-90, 1994.

3) 沈振江・石丸紀興: 広島市段原地区における土地区画整理事業後の街区画地 の幾何的特性からみた宅地用途の形成一コミュニティ住環境整備事業との 合併施行に上る土地区画整理事業の事例的考察一, 日本建築学会計画系論 文集No. 536, pp. $191-198,2000.10$.

4) Fulong Wu: A linguistic cellular automata simulation approach for sustainable land development in a fast growing region, Computers, Environment and Urban Systems, Volume 20, Issue 6, Pages 367-387,1996.

5) Cláudia Maria de Almeida, M. Batty \& others: Stochastic cellular automata modeling of urban land use dynamics: empirical development and estimation, Computers, Environment and Urban Systems, Volume 27,Issue 5, Pages 481-509,2003.

6) Benenson, P.M. Torrens: Geosimulation Automata-based modeling of urban phenomena. Wiley, England, 2004

7) Ivan Blecic, Arnaldo Cecchini, Paola Rizzi, Giuseppe A. Tronfio: Playing with Automata. An Innovative Perspective for Gaming Simulation (With CAGE Cellular Automata General Environment), 5C-3, CUPUM'03, Sendai, Japan, May 2003.

8) Erickson, B. and T. Lloyd-Jones: Experiments with settlement aggregation models. Environment and planning B, 24(6), 903-928, 1997.

9) 渡辺公次郎・大貝彰・五十嵐誠:セルラーオートマタを用いた市街地形態変 化のモデル開発, 日本建築学会計画系論文集, No. 533, pp. 105-112, 2000.7.

10)瀧澤重志・河村廣・谷明勲:セルオートマトンとしての都市（その 1) CA の匛用性と土地利用パターンの形成. 日本建築学会計画系論文集, No. 506, pp. 203-209, 1998. 4.

11) Makse, H.A.J.S.Andrade, M.Batty, S.Havlin, and H.E.Stanley: Modling urban growth patterns with correlated percolation. Physical Review E58(6):7054-7062, 1998. 